\title{
Enhancing Literacy in Enriching Academic Writing Capacity
}

\author{
Moh. Yamin ${ }^{1}$, Slamet Setiawan ${ }^{2}$ \\ Universitas Negeri Surabaya ${ }^{1}$, Universitas Lambung Mangkurat ${ }^{1}$, Universitas Negeri Surabaya ${ }^{2}$, Indonesia \\ Correspondence: Moh. Yamin, Universitas Negeri Surabaya, Universitas Lambung Mangkurat, Indonesia. e-mail: \\ mohyamin@ulm.ac.id \\ Received: September 14, 2019 \\ Accepted: October 10, 2019 \\ Online Published: October 11, 2019 \\ DOI: $10.29408 /$ veles.v3i2.1572.g932 \\ URL: http://dx.doi.org/10.29408/veles.v3i2.1572.g932
}

\begin{abstract}
This study was conducted to find out the importance of enhancing literacy for enriching the academic writing capacity. The expected study is that it has significance in teaching writing to produce new awareness through literacy and also aims to influence the paradigm in writing use for social practices. The descriptive qualitative method is applied. The data are taken from four research articles on literacy dealing with academic writing. Findings and results from each research article are the data for this study. Every finding and result of research article becomes the data source to discuss. The findings show that literacy contributes towards the success in academic writing. The good academic writing does not only deal with how the one writes, but also detects whether one's writing is the social reflection or not or respond to the social issues or not.
\end{abstract}

Keywords: literacy, social practices, and academic writing

\section{Introduction}

Facing the global challenge requires more capacity and one of them is literacy. The future dynamics should be in line with the one's capacity in delivering the meaning to the text so that this condition should be understood as the way of building the self-capacity. Literacy dealing with writing in a basic definition is the ability to formulate the ideas and the thought that are arranged into words, phrases, sentences, and text; this is called writing as composition (Williams, 2004). It means that writing as composition should be interpreted as the skill in which every language learner not only have the knowledge but also has the competence to understand it and translate it into the written form. Writing capacity as the composition should also be considered as the main competence in training himself or herself to be able to correct and right in using the grammar, language use, mechanics, organization, and content so that the text made and composed is effective and efficient writing. As a basic definition dealing with literacy, composition needs 
all learners to be familiar with what composition it is like and how composition in writing responds to the needs. To learn writing is not only as of the knowledge but also as social practice in order to be in tune with what should be written and discussed.

Writing connected with literacy should be meant to allow people to use language in order to enhance their capacity to think, to create, to question which helps them to become more aware of the world and empowers to participate more effectively in society (Dean, 2000). What Dean says is line with the perspective that those who are skilled in language literacy will be able to participate actively in social activity (Setiayadi and Piyakun, 2017). It is also in line with the perspective stating that literacy triggers all learners to be able to utilize the interior world of self to act upon and interact with the exterior structure of the world around them to make sense of self and other (Anstey and Bull, 1996).

Literacy in more detail is defined within a particular socio-cultural context in which practices and events take place. In detail, learning takes place in formal as well as informal context (Barton \& Hamilton, 1998; Baynham, 1995; Gee, 1996; Street, 1993, 2001). It means that social activities are the space for all learners in discussing and giving argumentation towards it. Every discussion and argumentation given is the result of the self-capability in uttering in written form. One of those who are able to discuss and make any argumentations dealing with the text in written form can be categorized as the ones who can think critically. Thinking critically is the main part of literacy in writing. Without thinking critically, literacy in writing does not exist. Critical thinking should be integrated with literacy in which critical thinking itself means to think out of box and literacy is the ability of writing that is based on wide knowledge, social knowledge, and social practices.

Literacy does not only deal with printed and written texts but it also takes the new forms of representation of the target language that is portrayed by digital technologies into consideration. Literacy is for all and anything can be the source as the inherent part of literacy. Literacy is not what we have in our mind, but how we use the mind to respond the fact and life reality. Language as the tool in expressing the thought for action should be defined as the social practice language in which the real language is the one that is used for doing the change. Language for social change is the one expressing the social interest for social change. Because language is for social change, the language requirements and challenges in current workplaces are no longer restricted to reading and writing paper-based texts in native and other foreign languages, but have extended into recognition, interpretation, comprehension, and appreciation of languages and cultures in different forms and in diverse literacy practices. Therefore, the literacy education should address the corresponding issues in order to better prepare students to participate in social and cultural activities in the modern society (Sang, 2017).

Literacy is an evolving practice that should reflect the shifts in contemporary cultures, communication strategies, and societies. Melissa poignantly described literacy as a practice in which we "make sense of and in the world" (Dharamshi, 2018) and it is the reflection of the linguistic and cultural resources that learners bring to the classroom (Street, 2001). It is supported by Lewison, Leland, and Harste (2008) stating that the meaning of literacy is asking us to 
imagine standing in the shoes of others, focusing on sociopolitical issues dealing with teaching not in a neutral form of social practice.

Writing as social practice in literacy had been researched by Ganapathy (2014), Muhammad (2015), Seban and Tavsanli (2015), Whitney (2019), and Meena and Wallace (2013) in which they found that students who were positively engaged in literacy practices reveal teachers' positive comments. Students improved their interest on their ESL writing lessons. It means that there is teaching process supporting the goal of acquiring literacy skills necessary for today's world. Therefore, academic literacy should be viewed as social practice in which those who write the text should be inherent in social practice, have social experience with the text, and narrate the experiences in the text (Kaufhold, 2017; Weiss-Magasic, 2012; Berger and Zezulkova, 2018; Ganapathy, 2016).

Lillis and Scott (2007) programmatically state that in AcLits research 'practice is privileged above text'. The term practice, or more specifically literacy practices, is central here to highlight the need to move beyond analyzing written texts and consider what people do around texts (Tusting et al., 2000). In this sense, the term connects individuals' writing and reading activities to wider culturally formed patterns, that is, to social practices (Barton and Hamilton, 2000; Street, 2003). Based on these considerations, this article aims to explore the importance of enhancing literacy in order to enrich the academic writing capacity. The significance of study is that it will contribute towards teaching writing for building new awareness about change through literacy and also mean to influence the paradigm in using writing for social practices.

\section{Method}

This research is a descriptive method with a qualitative approach. The descriptive performance is seen from how the data were narrated in a simple manner, clearly, and concisely so that data can give meaning. The qualitative performance is measured from how the data had the significance towards the goal of the research. Therefore, the descriptive method and qualitative approach are the research framework to make the findings in the discussion has valuable meaning contributing to the goal of the research. The analysis technique applied is content analysis based on the provided data.

\subsection{Participants}

The source of data was four research articles that elaborate on the role of literary supporting and strengthening academic writing competence. Therefore, the participant itself in this research was coming from four articles that have discussed the findings of literacy contributing to academic writing.

\subsection{Data Collection}

\subsubsection{Instrument of Collecting Data}

The instrument used to collect the data was documentation in which the researcher sought a number of research articles that elaborated and discussed literacy and academic writing intensively. Therefore, the data collected through documentation is based on the achievment 
indicators made by the research in order to produce the representative and qualified data responding to the aim of research.

\subsubsection{Techniques for Collecting Data}

In collecting the data through documentation, the researcher used any online sources, namely doaj.org, eric.org, and science direct. In the researcher's consideration, those are credible sources of articles because of being validated by DIKTI. The phase of collecting the data was started by determining keywords in order to be able to answer the research problem proposed in the research problem. It is followed by collecting and selecting the research articles considered available to research problem proposed. Finally, the researcher decided to take four articles to research and to discuss. The reason to take four articles is that all research articles dealing with literacy and academic writing have the same finding, however; there are some different ones in four articles in viewing literary to academic writing so that those are interesting to research, to get deep findings, and to discuss.

\subsection{Data Analysis}

The analysis technique applied is content analysis based on the provided data. The meaning of content analysis is that the research gave meaning, explaination, and elaboration so that the data found in research articles talk and inform the position of literacy to academic writing. It means that content analysis was meant to connent all findings in four research articles with theory literacy in teaching writing to students.

\section{Results}

Table 1. Literacies: Skills and Practices in Developing Writing Identity

\section{Title Finding}

Literacies: Skills and Pfeiffe (2018) conducted the research "Literacies: Skills and Practices in Developing Practices in Developing Writing Identity" in South Africa with the Writing Identity notion of a social (cognitive) process and its influence on their ability to write and his research findings state that multilingual students benefit from the use of expressive writing. When pondering the holistic view of these findings, this study endorses the use of expressive writing as a developmental tool in the process of becoming academically literate. Providing students with opportunities to construct their own stories can legitimize and validate their lived experiences and identities as valuable assets and resources to write. Supporting them to negotiate their L2 learning processes in multilingual and multicultural contexts and providing them with space to generate authentic narratives in order to explore their own language and cultural learning experiences, both in their home countries and in their new learning environment to determine their way of thinking. 
Table 1 affirms that students should be facilitated in strengthening literacy in order to have writing skill that focuses on exploring their own language and cultural learning experiences. The aim of facilitation is to teach them in constructing the way of thinking. Literacy aiming to think critically is the starting point for learners to be able to narrate their life experiences into the written form. Because the goal of literacy itself for writing is to make the learners closer to the environment, such thing determines the learning success in literacy.

Expressing writing used in this research is meant in order to make the learners able to negotiate their ideas and their capability in writing. Expressing writing is too close to the learners' life experiences because expressive writing practice is implemented based on simple ways, but it teaches them to think openly and naturally what they undergo.

Table 2. Engaging English as a foreign language students in critical literacy practices: The Case of a Teacher at a Private University

\begin{tabular}{|c|c|}
\hline Title & Finding \\
\hline $\begin{array}{l}\text { Engaging English as a } \\
\text { Foreign Language } \\
\text { Students in Critical } \\
\text { Literacy Practices: The } \\
\text { Case of a Teacher at a } \\
\text { Private University }\end{array}$ & $\begin{array}{l}\text { Jiménez and Gutiérre (2019) publish their research "Engaging } \\
\text { English as a Foreign Language Students in Critical Literacy } \\
\text { Practices: The Case of a Teacher at a Private University" and the } \\
\text { findings tell that when students engage in critical literacy practices, } \\
\text { they are prone to reflect on the power they have as agents of social } \\
\text { change, while developing language skills. However, teachers should } \\
\text { be ready to encounter some resistance from students and to struggle } \\
\text { with the incorporation of critical perspectives in their lessons, which } \\
\text { is understandable considering the emphasis grammar mastering has } \\
\text { traditionally had on language teaching and learning. It means that a } \\
\text { critical approach to English language teaching focuses on helping } \\
\text { learners becoming aware of the connection between language and } \\
\text { their social, cultural, and political lives. It is key to give students the } \\
\text { opportunity to explore, interrogate, and discuss texts, materials, and } \\
\text { topics that are related to their L1 culture. }\end{array}$ \\
\hline
\end{tabular}

Table 2 informs that critical literacy practices can be created and it will shape the learners' paradigm in reading and understanding the text when there is warm welcoming from the teacher. Guiding them to close to the social, cultural, and political lives help the learners to be the openminded learners so that this condition affects the learners' habit in interacting and meaning every social life traces. Taking the learners to discuss in a natural way and asking them to express their understanding experiences into written form.

The keyword to explore, interrogate, and discuss show that the learners should be treated as those who position themselves to be active in participating so that what they can do assist to habituate to use literacy in writing. The last keyword awareness is the final result in literacy as social practices and they are required to attain the achievement. 
Table 3. Unveiling social awareness through literacy practices in an EFL class

\section{Title Finding}

Unveiling social awareness Pérez (2013) also did the similar research about literacy through literacy practices in an EFL class

contributing to writing "Unveiling social awareness through literacy practices in an EFL class" and the findings say that inquiry along with writing about social issues in English allowed students to develop rationality and sensitivity towards violent acts, furthermore, inquiry about their social problems encouraged students to work collaboratively, to reflect about their social conditions and to apply the use of the English language in contextualized situations. Inquiry and reflection on social issues should be valuable elements to be implemented in the process of writing in EFL. It is important to start implementing pedagogical and social changes inside and outside school. In his finding, the lack of integration between students' realities and curricula is one of the main weaknesses evident at school. Narratives about students' aggressive experiences in EFL, for example, may be a good opportunity for students to reflect upon their attitudes and behaviors.

Table 3 explains that literacy practices supporting EFL students in writing should be conducted through unveiling social awareness. Unveiling social awareness is done through inquiry-based on social issues and this practice helps learners to develop rationality and sensitivity, to work collaboratively, to reflect on their social conditions and to apply the use of the English language in contextualized situations.

Inquiry in literacy is the simple word to mean critical thinking. What had been researched by Pérez gives an explanation that literacy is dealing with questioning, interrogating, discussing, and trying to find out the root of the problem in question. Literacy connected with writing is interpreted so that qualified writing is based on the capability in formulating the background, research problem, discussing the problem, and offering the solution towards the problem.

Table 4. Seeing, doing, writing: the write here project

\begin{tabular}{ll}
\hline Title & Finding \\
Seeing, Doing, Writing: & Rumney, Buttress, and Kuksa (2016) conducted the research \\
The Write Here Project & "Seeing, Doing, Writing: The Write Here Project" and this research \\
& result contributes towards literacy and writing. In their findings, it is \\
& stated that engaging young learners with creative, playful, \\
& multimodal activities will foster their confidence and motivation to \\
& engage with the subject and, more importantly, will lead to a \\
& significant improvement in literacy attainment. It will give
\end{tabular}


significant impact to foster their writing ability.

Table 4 states that so that the learners have high achievement in literacy, it is necessary to engage them in creative, playful, and multimodal activities because those activities aim to foster confidence and motivation. Creative, playful, and multimodal activities are those that trigger the learners to be able to express their life experiences in written form. Literacy in writing is that every learner should be familiar with the fact or data that will be written.

Rumney, Buttress, and Kuksa confirm that to be able to write must be based on the ability to see and do. Seeing is knowing the situation and condition; feeling it is necessary. Doing is to be able to have meaningful dealing with what has been seen. Seeing is not enough to be familiar with the situation and condition. Doing should be conducted so that what has been meant physically can have an impact psychologically. By undergoing these phases, it will be easy to express the experience in written form.

\section{Discussion}

The data that have been narrated in findings are the collections of findings stating that literacy is needed and aim to foster students' capacity in writing. Pfeiffe's finding (2018) dealing with strengthening literacies as skill and practices in developing writing identity in South Africa with the notion of a social (cognitive) process and its influence on their ability to write should be understood that it is necessary to provide students with opportunities to construct their own stories that can legitimize and validate their lived experiences and identities as valuable assets and resources to write. It means that constructing their own stories to validate experiences and identities are the main capital so that they can have the real experiences. The real experiences give any chances to develop the way of thinking and it is aimed to narrate in written form.

It is in line with what Sang (2017) says that literacy should be able to address students to respond the trend issues and drive them to participate in social and cultural activities in which the learners exist. Literacy is the way of thinking and responding the fact critically. When the learners have such capacity, it should be negotiated with linguistic competence they have. Conducting this, it is the point to generate the learners who are inherent in their environment and it will be easy for them in writing the issues in question.

Pfeiffe's finding (2018) is also in line with Jiménez and Gutiérre's finding dealing with engaging English as a foreign language in critical literacy practices: the case of a teacher at a private university (2019) explaining that engaging students will help them to develop language skills. Language skill should be trained and practiced. The way is through habituating them to respond the fact. Trying to connect lingustic competence in social, cultural, and political lives will create the awareness and this is the key for learners to be able to explore, interrogate, and discuss texts, materials, and topics relating to their L1 culture. Barton and Hamilton (2000) state that linguistic competence of the learners as individuals' activities and literacy practices must be seen as mutually shaping. Literacy practices will develop the way of thinking in which the learners should respond and narrate their experiences in written form as social practices. 
Jiménez and Gutiérre's findings (20019) can be called as the reflection what happens when Pérez (2013) did the research about literacy contributing to writing "unveiling social awareness through literacy practices in an EFL class". Inquiry in their paradigm is considered as the simple definition of literacy in which inquiry is aiming to question the social condition. Questioning is meant to discuss social problems. By questioning, it trains and teaches them learn to develop rationality and sensitivity. The feature of literacy is rationality and sensitivity itself; it is important to apply the use of the English language in contextualized situations so that the learners can narrate their experiences in written form. Linguistic competence in writing for literacy is meaningful when it is embedded in wider social practices in which literacy activities are shaped by ideological world views and power structures (Street, 2003). Ideological world views and power structures cannot stand strongly in the learners' paradigm as the ones practicing literacy through writing when the learners are not the part of social practices. Therefore, literacy in enriching academic writing capacity should be strengthened and practiced through social practices themselves so that the learners have their own experiences to narrate and to write.

What has been discussed by Jiménez and Gutiérre (2019) dealing with their findings affirm what is declared by Rumney, Buttress, and Kuksa (2016) stating that engaging learners through with creative, playful, multimodal activities help them to have confidence and motivation to engage so that the learners focus on the subject. As a result, it drive them to have significant improvement in literacy attainment and their writing ability is improved. The way of thinking and way of writing complete each other. Good and qualified thinking determine and become the capital in writing capacity. Writing capacity in well established one is the space for the learners in narrating and writing their life experiences in written form.

Based on those, it is important to state that good literacy contributes towards the success in academic writing. The good academic writing does not only deal with how the one writes, but whether his or her writing is the social reflection or not. The academic paper that is written and discussed in a academic manner but does not respond the social issue is not called literacy based paper. Literacy based paper is the one that is able to explore the social issues, discuss it, and close the text into social need so that the academic paper has the social benefit, not only academic benefit. The research papers that have been discussed give meaning towards social change.

\section{Conclusion}

Qualified writing capacity for the learners in expressing their life experiences should be enriched with literacy when they are inherent in their environment. The environment and experiences they have are aimed to be able to drive the learners in opening the mind and paradigm to think openly. Social practices in literacy contribute towards building critical paradigm so that the learners have framework of thinking based on social practices; writing skill as linguistic competence attends to help in translate their thought into the written from. Principally, writing is the process of thinking and writing product is the product of thought. Every product of thought in written form should be produced through literacy as social practices when the leaners want the qualified writing product responding the social issues. 


\section{References}

Anstey, M., \& Bull, G. (1996). The literacy labyrinth. Sydney: Prantice Hall.

Balgopal, Meena \& Wallace, Alison. (2013). Writing-to-Learn, Writing-to-Communicate, \& Scientific Literacy. American Biology Teacher, 75(3), 170-175.

Barton, D., and Hamilton, M. (1998). Local literacies. New York: Routledge.

Barton, D; Hamilton, M; \& Ivanič, Roz. [Eds]. (2000). Literacy practices. In Barton, D., Hamilton, M., and Ivanič, R. (eds). Situated Literacies: Reading and writing in context. (pp. 7-15). London: Routledge.

Baynham, M. (1995). Literacy practices: investigating literacy in social contexts. London: Longman.

Berger, Richard; Zezulkova, Marketa. (2018). A Remaking Pedagogy: Adaptation and Archetypes in the Child's Multimodal Reading and Writing. Education, 3-13, 46(1), 64-75.

Dharamshi, Pooja. (2018). "Seeing the Everyday through New Lenses" Pedagogies and Practices of Literacy Teacher Educators With a Critical Stance. Teacher Education Quarterly, 4, 7-29.

Dean, G. (2000). Teaching reading in secondary schools. London: David Fulton.

Ganapathy, M. (2016). The Effects of Using Multimodal Approaches in Meaning Making of 21st Century Literacy Texts Among ESL Students in a Private School in Malaysia. Advances in Language and Literary Studies, 7(2), 143-155.

(2014). Using Multiliteracies to Engage Learners to Produce Learning. International Journal of e-Education, e-Business, e-Management and e-Learning, 4(6). http://dx.doi.org/10.17706/ijeeee.2014.v4.355.

Gee, JP. (1996). Social linguistics and literacies: ideology in discourses (2nd ed.). London: Falmer Press.

Gómez Jiménez, M. C., \& Gutiérrez, C. P. (2019). Engaging English as a foreign language students in critical literacy practices: The case of a teacher at a private university. Profile: Issues in Teachers' Professional Development, 21(1), 91-105. https://doi.org/10.15446/profile.v21n1.71378.

Kaufhold, Kathrin. (2017). Tracing interacting literacy practices in master's dissertation writing. London Review of Education, 15(1), 73-83. DOI: https://doi.org/10.18546/LRE.15.1.07.

Lillis, T.M. and Scott, M. (2007). Defining academic literacies research: Issues of epistemology, ideology and strategy. Journal of Applied Linguistics, 4 (1), 5-32.

Lewison, M., Leland, C., \& Harste, J. C. (2008). Creating critical classrooms: $K-8$ reading and writing with an edge. New York, NY: Routledge.

Muhammad, Gholnecsar E. (2015). Iqra: African American Muslim Girls Reading and Writing for Social Change. Written Communication, 32(3), 286-316.

Pérez, Luzmel Alexánder. (2013). Unveiling social awareness through literacy practices in an EFL class. Colombian Applied Linguistics Journal, 15(2), 184-204. DOI 10.14483/udistrital.jour.calj.2013.2.a03. 
Pfeiffer, Verbra. (2018). Literacies: Skills and Practices in Developing Writing Identity. Per Linguam, 34(1):60-76. http://dx.doi.org/10.5785/34-1-741.

Rumney, P., Buttress, J., \& Kuksa, I. (2016). Seeing, Doing, Writing: The Write Here Project. SAGE Open, 6(1), 1 -11. DOI: 10.1177/2158244016628590.

Street, B. (2016). Literacy and Development: Ethnographic Perspectives. Symposium on the theme: "Education and the Sustainable Development Goals in the Commonwealth and Beyond: Shifting the Discourse" on April 26 - 27th, Hamilton House, Mabledon Place, London: The Ramphal Institute in collaboration with Education International. Retrieved from

http://www.ramphalinstitute.org/uploads/2/3/9/9/23993131/literacy_and_development_by_p rof_b_street.pdf.

(2003). What's "new" in New Literacy Studies? Critical approaches to literacy in theory and practice. Current Issues in Comparative Education, 5(2), 77-91.

. (1993). Introduction: the new literacy studies. In Street, B (Ed.). Cross-cultural approaches to literacy. (pp. 1-22). Cambridge: Cambridge University Press.

Sang, Yuan. (2017). Expanded Territories of "Literacy": New Literacies and Multiliteracies. Journal of Education and Practice, 8(8), 16-19.

Seban, Demet; Tavsanli, Ömer Faruk. (2015). Children's Sense of Being a Writer: Identity Construction in Second Grade Writers Workshop. International Electronic Journal of Elementary Education, 7(2), 217-234.

Tusting, K., Ivanič, R., and Wilson, A. (2000). New literacy studies at the interchange. In Barton, D., Hamilton, M., and Ivanič, R. (eds). Situated Literacies: Reading and writing in context. (pp. 210-18). London: Routledge.

Williams, Eddie. (2004). Literacy Studies. In Alan Davis and Catherine Elder. Editor (Eds.), The Handbook of Applied Linguistics (pp. 576-603). Malden: Blackwell Publishing.

Weiss-Magasic, Coleen. (2012). Writing and Science Literacy. Science Teacher, 79(1), 41-43. Whitney. (2019). Reenvisioning Writing Pedagogy and Learning Disabilities through a Black Girls' Literacies Framework. Journal of Adolescent \& Adult Literacy, 62(6), 643-651. 